\section{Taking the waters in Banff, Alberta}

I n January I884, William and Tom McCardell were working on the Canadian Pacific Railway on the site of present-day Banff, Alberta. Being observant types, they noticed a wisp of mist rising from the mountainside. Curious, they clambered further up the slope, finding steam escaping from a gash in the rock.

Further investigation led them to enjoy a dip in the mineral-rich waters of a sulpherous-smelling spring, likely making them the first white men to luxuriate in what became Banff's renowned Upper Hot Springs at Sulphur Mountain.

For perhaps a few thousand years, however, Aboriginals have considered such sites sacred because they associated the heated mineral waters with miraculous healing powers. In fact, in some Aboriginal cultures, such as the Lakota, hot springs were considered neutral ground where even warriors from warring tribes could soak up some relaxation, unharmed.

Such spirituality eluded the McCardell brothers. Instead, they envisioned making their fortunes. Why not lay claim to the land, build a pool enclosure, and charge visitors for the luxury? They knew Europeans had been flocking to spas for centuries to "take the waters" and treat everything from infertility to rheumatism and paralysis. People even drank the waters and bottling businesses prospered. According to Dr. William A. Frosch at Weill Cornell Medical College, famous people have flocked to spas for centuries: Michelangelo claimed a kidney stone was broken up by the Italian waters at Fiuggi and the Igth century explorer and evolutionary biologist, Charles Darwin, took the waters for dyspepsia (which was defined, at the time, as physical weakness, loss of appetite and depression, morbid despondency \& and gloom). ${ }^{1}$ In his diary, Darwin noted, that the waters had "an astonishingly renovating action on my health." He assured a friend that, "I feel certain that the water cure is no quackery."

The McCardell brothers were likely unaware of these famous mineral bath enthusiasts, but they were astute enough to realize they could make their fortune by building bathhouses and bathing pools. They erected a wooden shack at the site, thus establishing squatter's rights, and began charging people to use the sulfurous springs. They then presented their discovery to William Cornelius Van Horne, the Canadian Pacific Railway's general manager, who was trying to find a way to complete the transCanada railway.

Van Horne declared the springs "worth a million dollars" and offered the McCardells \$675 each, which they accepted. Now Van Horne possessed the perfect hook to convince the government to conserve the area's spectacular mountain scenery as a national preserve - and tourism Mecca. At the same time, Van Horne's and the government's funding problem was solved: tourists would bankroll the Canadian Pacific Railway. In I885, Banff National Park was born.

Van Horne's plans geared up. He envisioned a series of luxury hotels to accommodate wealthy visitors who would, of course, arrive by train. On June I, I888, the Banff Springs Hotel opened its doors, one of a string of Canadian Pacific hotels across the country. From the confluence of the Spray and Bow rivers in Banff, horse-drawn carriages conveyed well-todo Victorians from Philadelphia, Boston, New York and other centres to the Upper Hot Springs bathhouse for "the cure." Meanwhile, less well-heeled visitors stayed at the Grand View Villa hotel, built adjacent to the hot springs in 1886.

Not only did tourists soak in the spring water, they drank it, too. Bob Elliott, acting operations manager at Banff Upper Hot Springs, said, "Local bars sold bottled hot springs water as a tonic and cure for hangovers. Banff's mineral water was bottled and sold as 'Lithia water' for a short time until the medical experts realized that one of the active ingredients found naturally in the hot springs, Lithium, was addictive. This ended the bottling and consumption, by drinking, of Banff's mineral springs."

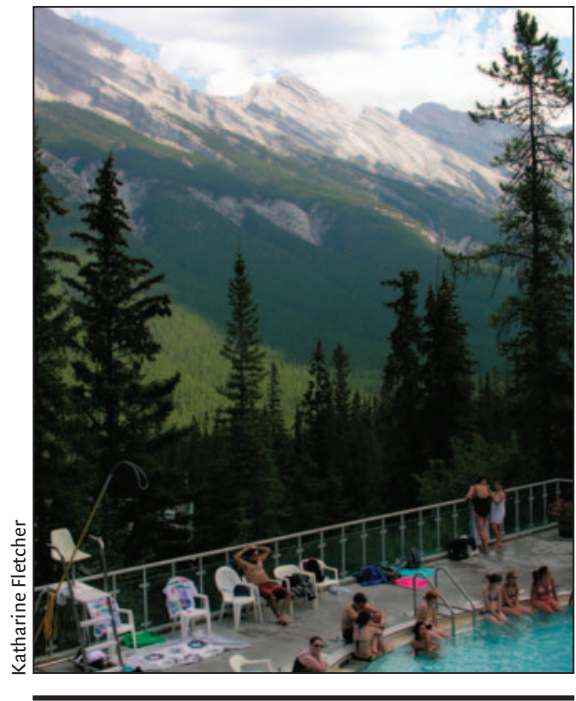

Some 300000 visitors now "take the waters" at the Banff Upper Hot Springs, which celebrated the $75^{\text {th }}$ anniversary of its opening last year.

All and sundry came to soak outside in the steaming mineral waters, which possessed what Van Horne knew was a compelling scene of majestic beauty: a sweeping backdrop of Sulphur, Rundle and Cascade mountains. Time passed - bathers indulged - and, in 1932 , the Government of Canada erected the present bathhouse, which has been recently renovated. A heritage treasure, it is a distinctive Queen Anne Revival architectural style, finished - just as is the Banff Springs Hotel - in Rundle Stone. Last year marked the $75^{\text {th }}$ anniversary of its opening and, over the past decade, it has steadfastly attracted some 300000 visitors annually.

Regardless of their medical benefits, the Banff mineral waters do offer the undiluted, exquisite pleasure of soaking up the heat amid spectacularly scenic nature.

\section{Katharine Fletcher BA Quyon, Que.}

\section{REFERENCES}

I. Frosch WA. "Taking the waters" - springs wells, and spas. Journal of the Federation of American Societies for Experimentation in Human Biology 2007;21:1948-50.

2. Chisholm B, Floren R, Gutsche A. Castles of the North, Canada's Grand Hotels, Toronto: Lynx Images Inc; 200I. p. 29. 